\title{
U.S. Geological Survey Response to Flooding in Texas, May-June 2015
}

As a Federal science agency within the Department of the Interior, the U.S. Geological Survey (USGS) collects and disseminates streamflow stage and discharge information (http://www.usgs. gov/water/) along with other types of water information as a major part of its Water mission area (http://water.usgs.gov/ about_WRD.html). Data collected at USGS streamflow-gaging stations (hereinafter referred to as "streamgages") are used for a variety of purposes including flood warning, engineering design, management of water resources, and scientific research.

During flood events, the need for timely, accurate, and complete streamflow data is underscored because these data are relied on by local, State, and Federal emergency management personnel for flood response purposes. For example, the National Weather Service (NWS) uses the data from USGS streamgages to develop flood forecasts for specific locations on a river (National Weather Service, 2016). Tasks that the USGS performs in response to floods include monitoring the operation of gages and responding to any interruptions in data collection, calibrating and verifying stage-discharge ratings, and documenting extreme events including peak stage and peak discharge.

Frequent, severe storms during May and June 2015 caused widespread flooding in Texas. By various measures, the storms that caused the flooding were extreme and persistent. May 2015 was the wettest month on record for Texas, with a statewide average precipitation of 9.06 inches (National Oceanic and Atmospheric Administration, 2016). In comparison, the long-term statewide average monthly precipitation is

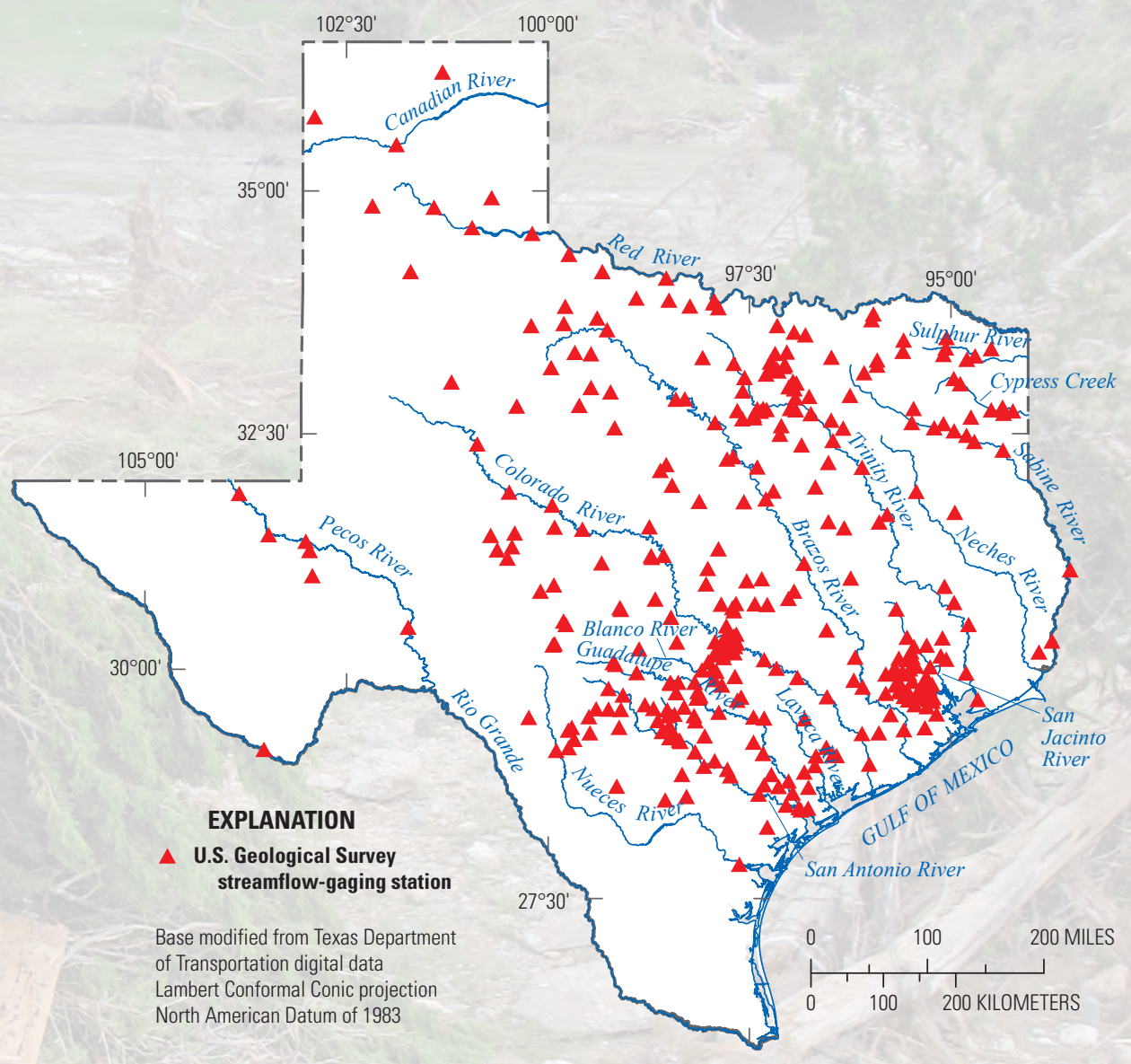

Figure 1. Major rivers in Texas and U.S. Geological Survey streamflow-gaging stations where direct measurements of discharge were made during the period from May 1 to June 15, 2015.
3.37 inches, with the previous record average monthly precipitation reported as 6.66 inches during June 2004 (National Oceanic and Atmospheric Administration, 2016). The Office of the Texas State Climatologist compiled monthly precipitation amounts for 19 selected cities throughout Texas and for 1 city in Louisiana; the total monthly precipitation amounts exceeded the monthly normal precipitation for 18 of the 19 selected cities
Stage is the height of the surface of a stream measured in reference to the known elevation of an arbitrary datum. The stage is used to compute streamflow (discharge) - the total volume of water that flows past a specific point on a stream in a given period of time (commonly expressed as cubic feet per second). in Texas, with 5 of these cities exceeding their previous record for the month of May (Texas A\&M University, 2015).

The onset of abundant precipitation in May 2015 resulted in the NWS flood stage being exceeded at USGS streamgages on numerous rivers. The widespread and prolonged nature of the flooding was unusual; most flood events in Texas are localized, typically affecting only one or two river basins and generally lasting only a few days (Liscum and East, 1994; Raines and others, 1998; Slade and Persky, 1999; Winters, 2012). With the exception of the Rio Grande, flooding was widespread May-June 2015 (fig. 1). in all of the major rivers in Texas during 


\section{Operation of Gages}

During the May-June 2015 flood event, the USGS provided real-time stage and stream discharge data from approximately 490 USGS streamgages in Texas. In addition to streamgages, the USGS operates gages to collect water-quality, reservoir, and groundwater data throughout Texas. Although this fact sheet focuses on severe storms and resulting streamflow, the data collected by all of these gages are useful for evaluating changes in hydrologic conditions resulting from flood events and must be reliable, accurate, and timely.

Most USGS gages are programmed to record data every 15 minutes and to transmit data via the Geostationary Operational Environmental Satellite (GOES) system every 60 minutes. One metric of the reliability of the USGS network of different types of gages during events such as the May-June 2015 flood event can be calculated as the number of instantaneous unit values available for each gage during the event divided by the total number of possible instantaneous unit values for that gage. From May 1 through June 30, 2015, this metric of reliability was determined for a combined 634 USGS streamflow, water-quality, reservoir, and groundwater gages operated by the USGS in Texas. Approximately 98 percent of the possible instantaneous unit values from May 1 through June 30, 2015, were recorded, transmitted, and entered into the USGS National Water Information System (http://waterdata.usgs.gov/tx/nwis/nwis).
The missing 2 percent of the instantaneous unit values were caused by a variety of issues. The most common issues were equipment malfunction and the damage or destruction of streamgages caused by flooding. On the Blanco River, which underwent some of the most severe flooding, two streamgages were destroyed by high flows. The gage shelters that were destroyed on the Blanco River had been installed at elevations appreciably higher than the stage elevation associated with previous flood peaks but, because of the extreme nature of this event, were inundated by the rapid rise in stage. At USGS streamgage 08171000 , Blanco River at Wimberley, Tex., in just 3 hours the river rose to a stage of 40 feet $(\mathrm{ft})$ - an increase of approximately $35 \mathrm{ft}$ from the 5 -ft base-flow stage before the river began to rise (fig. 2). When the stage reached $40 \mathrm{ft}$, inundation and flood damage caused data collection by the gage to cease; the gap in stage data in figure 2 corresponds to the period when the gage was inundated. Independent high-water marks, surveyed after the event, showed that water rose an additional $5 \mathrm{ft}$ (after gage inundation) and reached a peak stage of $44.90 \mathrm{ft}$; for reference, the NWS flood stage is $13.0 \mathrm{ft}$ (fig. 2). In response to the damage, on the following day (May 25, 2015), a new, temporary gage was installed at the location and began transmitting data (fig. 3).

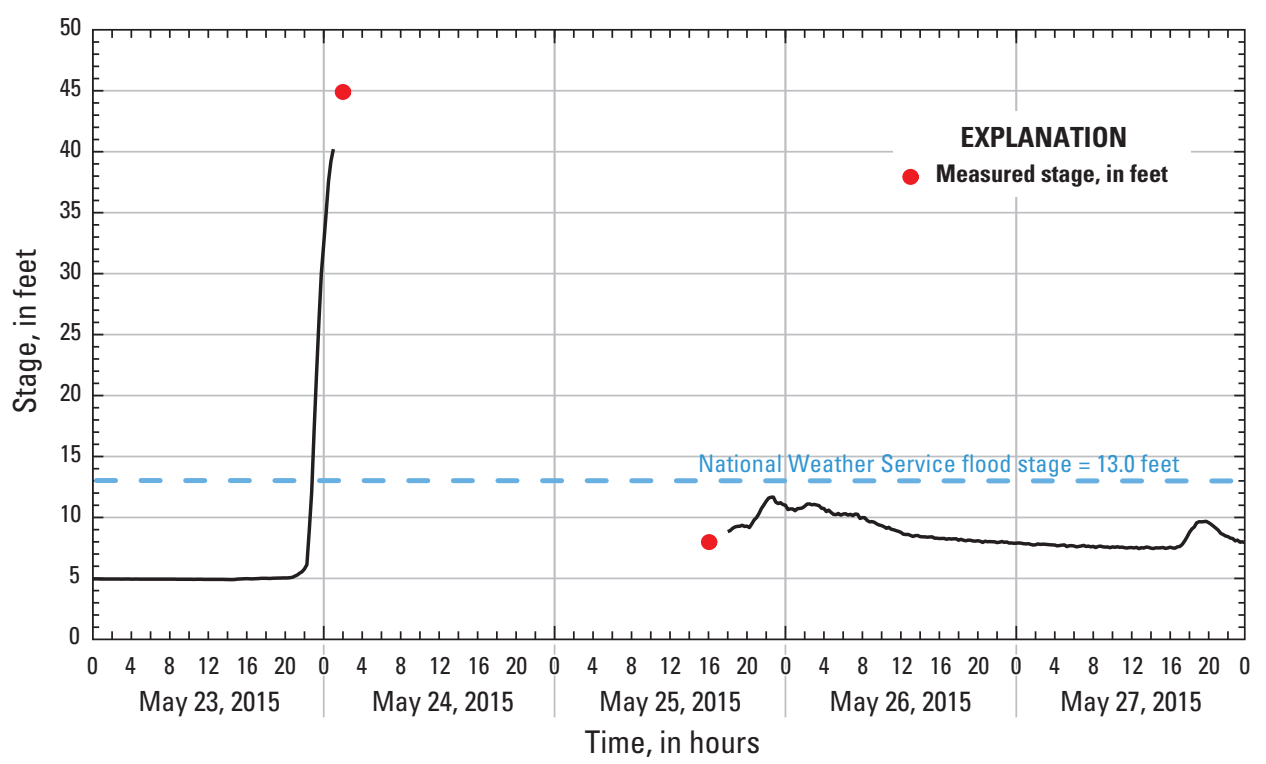

Figure 2. Recorded stage from May 23 to May 27, 2015, at U.S. Geological Survey streamflow-gaging station 08171000, Blanco River at Wimberley, Texas.
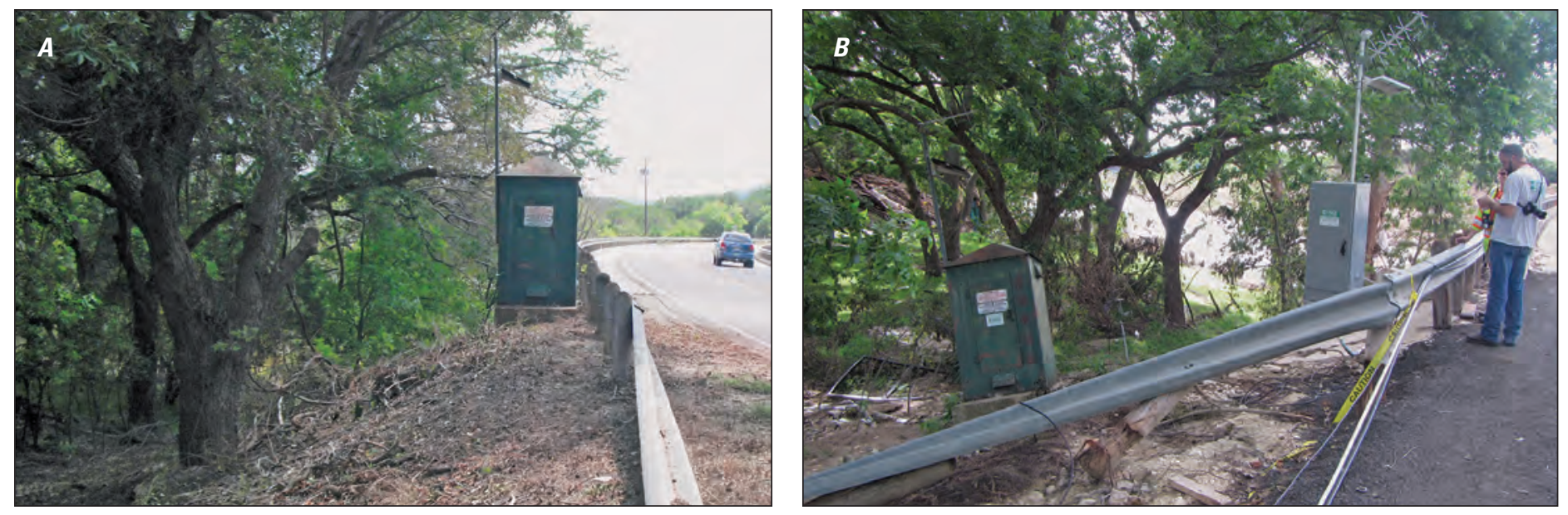

Figure 3. U.S. Geological Survey streamflow-gaging station 08171000, Blanco River at Wimberley, Texas, before and after the flood of May 23-24, 2015. A, The streamflow-gaging station in 2011. B, The streamflow-gaging station after being damaged by the flood (the new, temporary gage is visible in the upper right). 


\section{Verifying Stage-Discharge Ratings}

At most streamgages, stage data are collected and used to estimate streamflow on a continuous basis (a few gages are designed to collect only specific types of flow information, such as peak stage). For the continuous streamflow gages, a stagedischarge rating is developed, which establishes the relation between the full range of stage and streamflow at a given gage. To develop and verify the rating, discrete measurements of discharge are made, with corresponding stream stage measurements, over the range of expected flow (Rantz and others, 1982). Discrete discharge measurements involve making direct measurements of velocity, depth, and width and applying standard computation methods as described in Turnipseed and Sauer (2010).

Because the relation between stage and streamflow can change gradually or rapidly as changes to the channel occur, the stage-discharge rating is regularly updated. It is important to make discharge measurements during periods of high flow to maintain accurate stage-discharge ratings. From May 1 to June 15, 2015, which is when most of the flooding occurred, the USGS made 739 discrete discharge measurements at 420 streamgages (fig. 1). For comparison, during the same period in 2014, when high flow related to flooding was rare, 590 measurements were made at 388 streamgages.

Because most flood events in Texas are typically of short duration (1-2 days), the opportunity to make discharge measurements during high flow is brief. The extended duration of the May-June 2015 flood event allowed for the collection of more discharge measurements at many streamgages where additional verification of the stage-discharge rating was desired. Figure 4 depicts an example of the collection of several discrete measurements of discharge during high flow at USGS streamgage 07312500 , Wichita River at Wichita Falls, Tex.

\section{Shifting Stage-Discharge Rating Curves}

Over time, the conditions that control the stage-discharge relation at a streamgage can change. An example of this would be the deposition of sediment or debris on the low-water control (bed of the stream channel) during a period of low flow followed by the removal of the same material during a period of high flow. Discharge measurements are used to verify if the existing stagedischarge rating accurately reflects current conditions or if a change to the control conditions, as described above, has occurred. In those instances when the discharge measurement sufficiently verifies the existing stage-discharge rating, the rating remains in effect and is used directly to compute discharge. In those instances when a significant change to the control conditions is identified, however, the stage-discharge rating must be adjusted. The USGS applies temporary "shift adjustments" (Rantz and others, 1982), which are based on recent discrete discharge measurements, to the stagedischarge rating to represent the changes in control conditions (fig. 5).

To determine whether a change to the control conditions is significant and a shift adjustment to the stage discharge rating is required, various factors are considered, including the quality of the discharge measurement, the difference between the discharge measurement and the predicted value from the existing stage-discharge rating, and physical examination of control conditions during the measurement (Turnipseed and Sauer, 2010).

\section{Extending Stage-Discharge Rating Curves}

Discharge measurements made during flood events are commonly used to extend stage-discharge rating curves (fig. 6). An extension of the stagedischarge rating curve is required when the existing rating curve does not include a stage-discharge combination that occurs during a large flood event. In this situation, it becomes important to make discharge measurements as close to the peak stage as possible so that the extension of the stage-discharge rating curve is based on measured stage and discharge values.

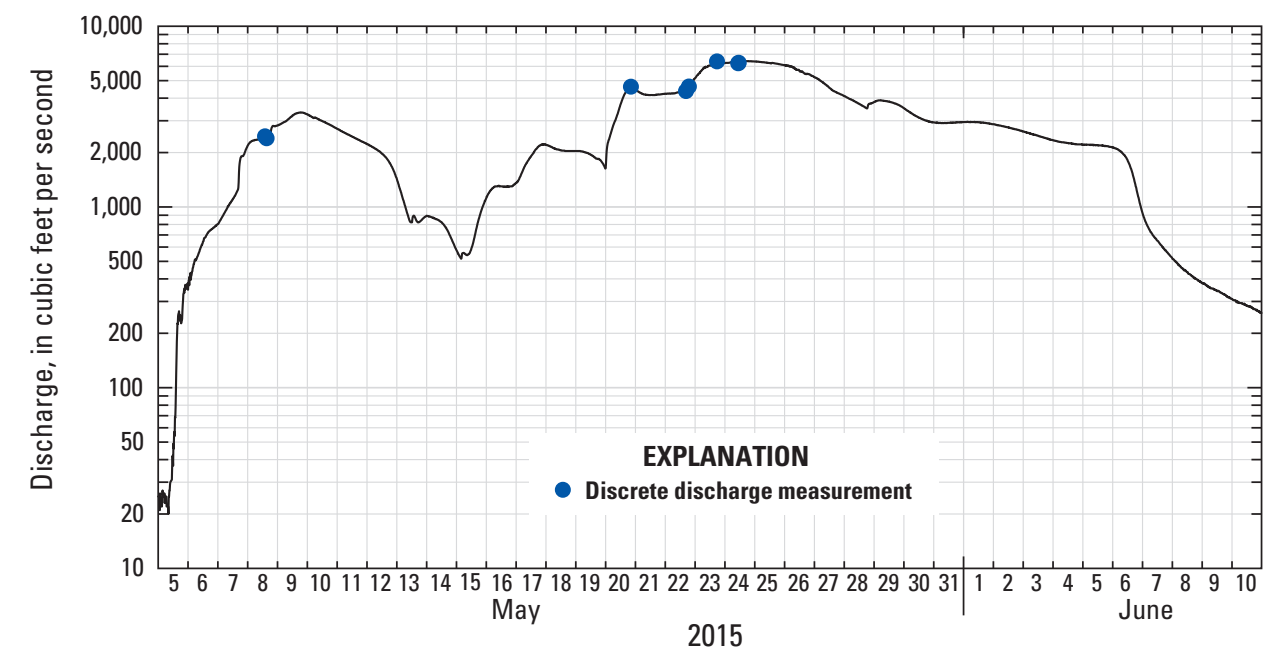

Figure 4. Time-series graph of discharge and discrete discharge measurements at U.S. Geological Survey streamflow-gaging station 07312500, Wichita River at Wichita Falls, Texas, for May 5-June 10, 2015.

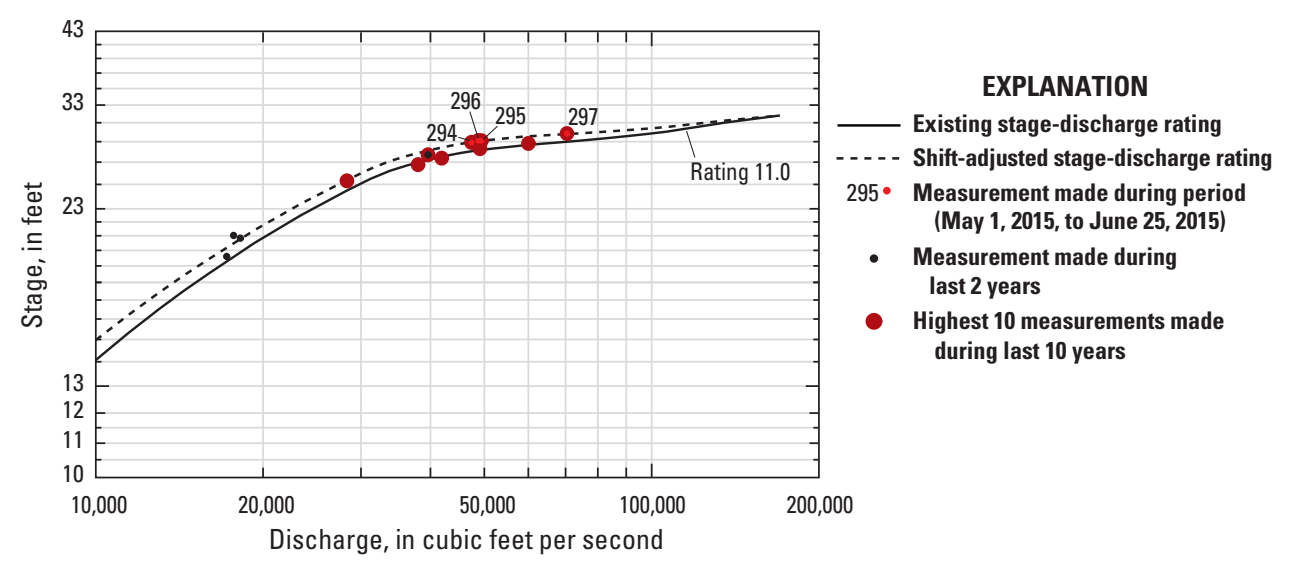

Figure 5. Example of a shift-adjusted stage-discharge rating curve. 


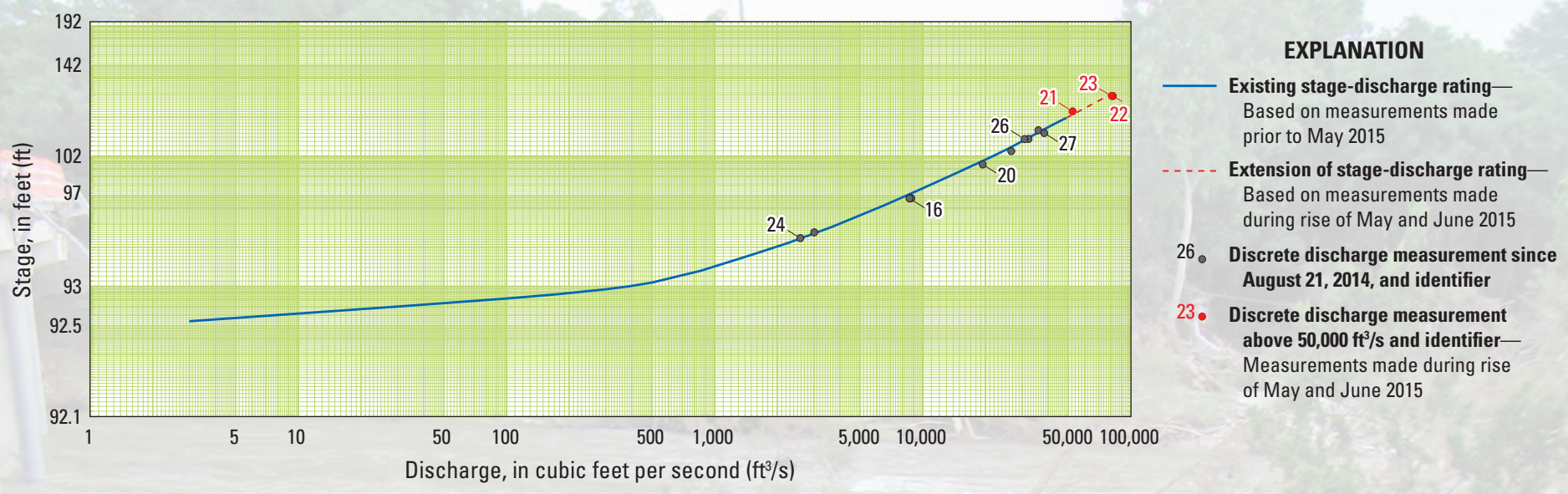

Figure 6. Example of extending a stage-discharge rating curve.

An example of a rating curve that was extended on the basis of three discharge measurements $(21,22$, and 23$)$ made during the May-June 2015 flood event is depicted in figure 6. Measurements 21-23 were used to extend the rating from 50,000 cubic feet per second to about 90,000 cubic feet per second (fig. 6).

\section{Peak Stage and Discharge}

The magnitude of a flood event can be put into historical context by comparing the peak stage and discharge determined for that flood for a location to the previously determined peak stage and discharge for that same location. The USGS identified streamgages at which the peak discharge during the May-June 2015 flood event exceeded the previously determined peak discharge for the entire period of record at that gage (fig. 7). The USGS WaterWatch Web page (http:// waterwatch.usgs.gov/?m=flood\&r=tx) summarizes information, such as previously determined peak discharge and current event peak discharge, for USGS streamgages and is a resource for data that may be used to provide historical context for current flooding.

\section{References}

Liscum, Fred, and East, J.W., 1994, Floods in southeast Texas, October 1994: U.S. Geological Survey Fact Sheet 94-073, 2 p. [Also available at http://pubs.usgs.gov/fs/ fs-073-94/.]

National Oceanic and Atmospheric Administration, 2016, National overviewMay 2015: National Oceanic and Atmospheric Administration, National Centers for Environmental Information, accessed February 16, 2016, at https://www.ncdc. noaa.gov/sotc/national/201505.

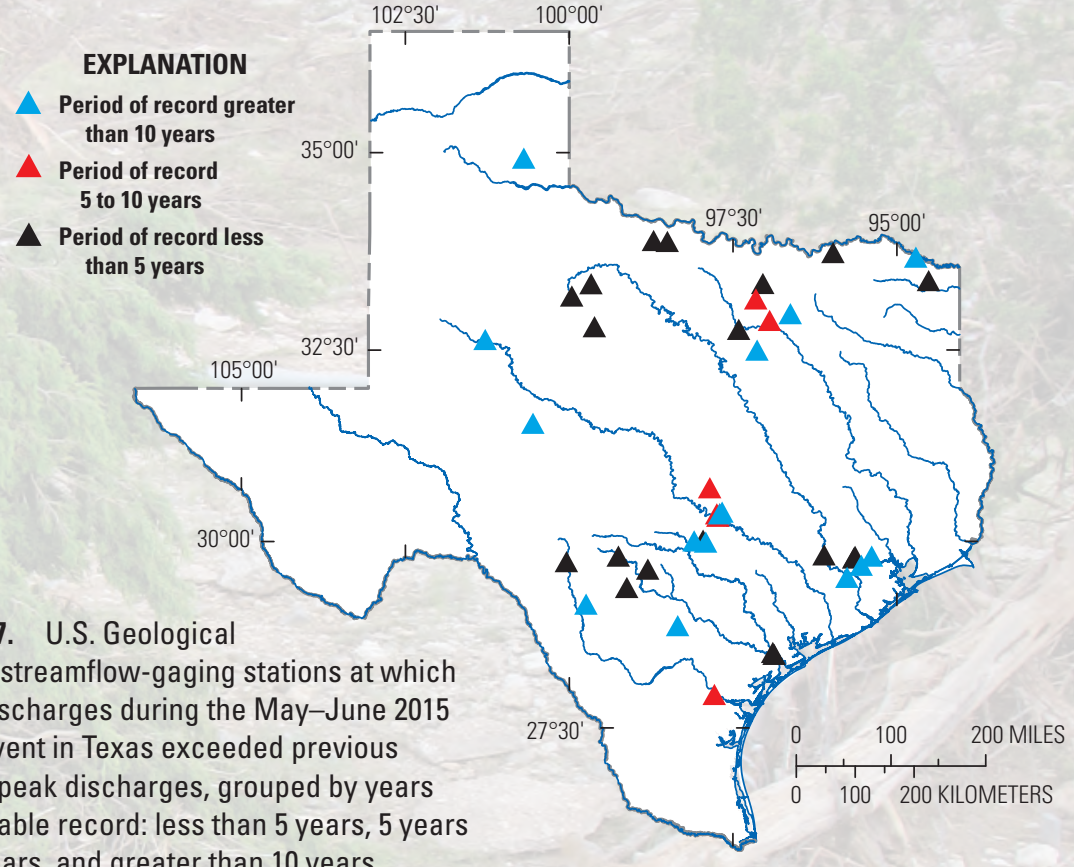

Figure 7. U.S. Geological Survey streamflow-gaging stations at which peak discharges during the May-June 2015 flood event in Texas exceeded previous record peak discharges, grouped by years of available record: less than 5 years, 5 years to 10 years, and greater than 10 years.

National Weather Service, 2016, National Weather Service reference guide: Accessed February 16, 2016, at http://www.crh.noaa.gov/Image/ mkx/pdf/NWS_Reference_Guide.pdf.

Raines, T.H., Asquith, W.H., and Brown, D.S., 1998, Floods in south-central Texas, June 1997: U.S. Geological Survey Fact Sheet 053-98. [Also available at https:// pubs.er.usgs.gov/publication/fs05398.]

Rantz, S.E., and others, 1982, Measurement and computation of streamflow: U.S. Geological Survey Water-Supply Paper 2175, v. 2, 631 p. [Also available at http://pubs. usgs.gov/wsp/wsp2175/html/wsp2175 vol2.html.]

Slade, R.M., and Persky, Kristie, 1999, Floods in the Guadalupe and San Antonio River Basins in Texas, October 1998: U.S. Geological Survey Fact Sheet 147-99, 4 p. [Also available at http://pubs.usgs.gov/ fs/FS-147-99/.]
Texas A\&M University, 2015, Climatic bulletins-May 2015: Texas A\&M University, Office of the State Climatologist, accessed July 12, 2015, at http://climatexas.tamu. edu/climatic-bulletins/may-2015/.

Turnipseed, D.P., and Sauer, V.B., 2010, Discharge measurements at gaging stations: U.S. Geological Survey Techniques and Methods, book 3, chap. A8, 87 p. [Also available at http://pubs.usgs.gov/tm/tm3-a8/.]

Winters, K.E., 2012, Floods in central Texas, September 7-14, 2010: Texas Water Journal, v. 3, no. 1. [Also available at https://journals.tdl.org/twj/index.php/ twj/article/view/3292.]

For more information, please contact: Director, Texas Water Science Center U.S. Geological Survey 1505 Ferguson Lane Austin, TX 78754-4501 http://tx.usgs.gov/ 